\title{
ENTRAINMENT HEAT FLUX COMPUTED WITH LIDAR AND WAVELET TECHNIQUE IN BUENOS AIRES DURING LAST CHAITÉN VOLCANO ERUPTION
}

\author{
Ezequiel Eduardo Pawelko ${ }^{1}$, Jacobo Omar Salvador ${ }^{1}$, Pablo Roberto Ristori ${ }^{1}$, \\ Juan Vicente Pallotta ${ }^{1}$, Lidia Ana Otero ${ }^{1}$, Eduardo Jaime Quel ${ }^{1}$ \\ ${ }^{1}$ CEILAP (CITEDEF-CONICET), UMI-IFAECI-CNRS 3351, Juan B. de La Salle 4397, B1603ALO, Villa \\ Martelli, Buenos Aires, Argentina, E-mail: epawelko@citedef.gob.ar
}

\begin{abstract}
At Lidar Division of CEILAP (CITEDEF-CONICET) a multiwavelength Raman-Rayleigh lidar optimized to measure the atmospheric boundary layer is being operated. This instrument is used for monitoring important aerosol intrusion events in Buenos Aires, such as the arrival of volcanic ashes from the Chaitén volcano eruption on May 2008. That was the first monitoring of volcanic ash with lidar in Argentina. In this event several volcanic ash plumes with high aerosol optical thickness were detected in the free atmosphere, affecting the visibility, surface radiation and therefore, the ABL evolution. In this work, the impact of ashes in entrainment flux ratio is studied. This parameter is obtained from the atmospheric boundary layer height and entrainment zone thickness using algorithms based on covariance wavelet transform.
\end{abstract}

\section{INTRODUCTION}

The Atmospheric Boundary Layer (ABL) is the lowest layer that is directly influenced by the Earth's surface. It responds to surface forcing by frictional drag, evaporation and transpiration, and sensible heat transfer with a timescale of one hour or less [1]. The ABL height is variable in time and space, ranging typically from a few hundred meters up to $1-3 \mathrm{~km}$, depending on the nature of the surface and on the meteorological conditions [2]. So, the ABL acts as a reservoir of chemical species where the solar radiation triggers photochemical processes [3].

The lidar (LIght Detection And Ranging) technique is a powerful tool to obtain the boundary layer structures and its evolution with high spatial and time scale resolution. Lidars are able to identify several dynamic parameters of the ABL, using aerosols as tracers of atmospheric dynamics, such as Mixing Layer Depth (MLD) and Entrainment Zone Thickness (EZT). The MLD is the height of the ABL in which pollutants are dispersed by the action of turbulence [4]. Measurements, parameterizations and predictions of the MLD have many theoretical and practical applications such as the forecast of pollutant concentrations and surface temperature, turbulence scaling measurements or the treatment of the mixed layers in numerical weather prediction and climate models [5].

The MLD can be resolved by different methods, however algorithms based on Covariance Wavelet Transform (CWT) [6] [7] [8] are preferred because of their simplicity, robustness and low computational cost. The EZT is the region at the top of the mixed layer where the free atmosphere above is entrained downward into the mixed layer, and thermals overshoot upward of the mixed layer [9]. This is an important variable that has received little attention due to the difficult measurement. Currently, an iterative algorithm based on CWT to identify these transition layers is used [10].

The effectiveness of EZT and MLD recognition algorithms based on CWT has been tested on lidar measurements with boundary layers, well defined and free of clouds and pollution plumes.

Entrainment Heat Flux (EHF) represents the amount of energy that is supplied to the $\mathrm{ABL}$ due to the entrainment processes. It is another important parameter that could be easily computed using the EZT and MLD results. The EHF calculated with lidar profiles has high temporal resolution, unlike the radiosonde data obtained [11].

In Argentina, a lidar network to monitor atmospheric aerosol events, such as those produced by volcanic eruptions is being built [12]. The ABL monitoring behavior is one of the main objectives [13]. A prominent ABL study of aerosol intrusion occurred on May $9^{\text {th }}$ and $10^{\text {th }}, 2008$, in Buenos Aires. In this event the aerosol lidar of CEILAP (34³3' S; 58 $30^{\prime} \mathrm{W} ; 17 \mathrm{~m}$ asl) registered volcanic ash plumes from the Chaitén volcano $\left(42^{\circ} 50^{\prime} \mathrm{S} ; 7^{\circ} 39^{\prime} \mathrm{W} ; 962 \mathrm{~m}\right.$ asl), that was erupting at that moment [14]. The measurements showed dense aerosol plumes that affected the surface radiation, visibility, $\mathrm{ABL}$ and therefore the typical EHF evolution. The study of this case is important because it was the first time that a volcanic eruption was measured and studied with lidar techniques in Argentina. 


\section{METHOD AND RESULTS}

\section{2.a. Instrumentation}

The lidar system located at the Lidar Division was designed to monitor the ABL evolution. On May 2008, the instrument was operating with a biaxial overlap configuration. The distance between the emission and the reception was about $30 \mathrm{~cm}$, therefore the blind zone was approximately $300 \mathrm{~m}$. The transmitter was a Nd:YAG laser model Continuum Surelite III P-IV operating at $10 \mathrm{~Hz}$ repetition rate and $650 \mathrm{~mJ}$ @ 1064 $\mathrm{nm}$. The backscattered light was collected with a Newtonian telescope of $0.5 \mathrm{~m}$ diameter and $1 \mathrm{~m}$ focal length. In the focus of the telescope there was a $1 \mathrm{~mm}$ diameter optical fiber. The data acquisition system had a $20 \mathrm{MHz}$ sampling rate and a $7.5 \mathrm{~m}$ vertical resolution [15].

\section{2.b.- Identification of boundary layers}

The detection of the ABL structures was done using a Covariance Wavelet Transform and Haar function based algorithm. A combination of the ABL height recognition based on wavelet variance technique and the EZT retrieving based on the iterative wavelet method are synergistically applied to enhance the recognition. First of all, clouds and aerosol plumes are identified and removed in free troposphere of the lidar profiles. This is done automatically using the minimum wavelet dilation with the algorithm proposed by [16]. Then, wavelet variance technique is used in the clean profile to detect the ABL height region. This result is used as a pointer to identify the area where the entrainment zone has to be calculated. EZT is correctly identified with the iterative algorithm based on CWT whenever the upper and lower limits around the pointer are previously calculated. Finally, the MLD is the altitude in the middle of EZT.

This algorithm reduces detection errors because of clouds and aerosol plumes along the lidar profile and it can be applied to extract diurnal and nocturnal boundary layers.

Figure 1 shows a $1064 \mathrm{~nm}$ lidar backscatter on May $9^{\text {th }}$ and $10^{\text {th }} 2008$ with volcanic ash in the free atmosphere which affects the typical ABL evolution. This measurement shows that the ABL has a lower MLD in the second day than the one during the first day.

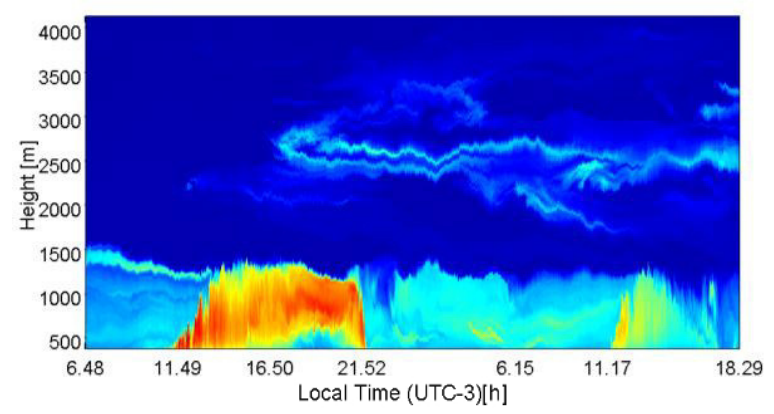

Figure 1. Lidar measurement at $1064 \mathrm{~nm}$ (one minute temporal averaged) on May $9^{\text {th }}$ and $10^{\text {th }} 2008$ in Buenos Aires. Volcanic ashes of Chaitén volcano in eruption at that moment can be seen in the free atmosphere.

Figure 2 shows the ABL height evolution calculated with wavelet variance method.

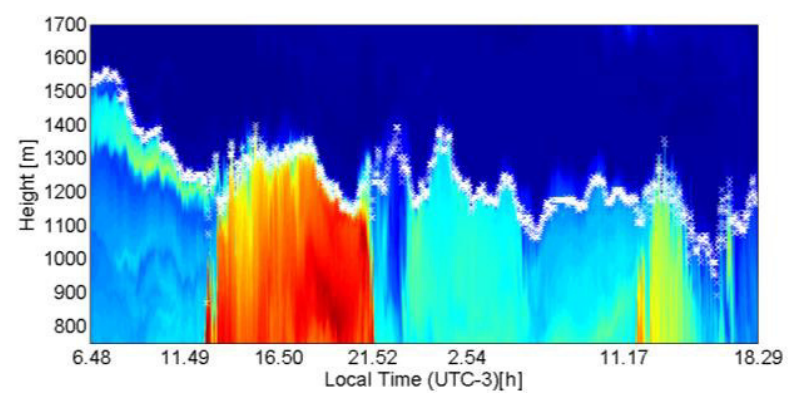

Figure 2. Daytime and nocturnal (residual) ABL height evolution retrieved with wavelet variance technique.

Figure 3 shows the result of the combined method used over the entire matrix of lidar measurements. Figure 4 shows the evolution of ABL height and upper and lower limits of the transition zone for convective ABL on May $9^{\text {th }}$ and $10^{\text {th }}$. The MLD is the mean value between the upper and lower limits of the EZT.

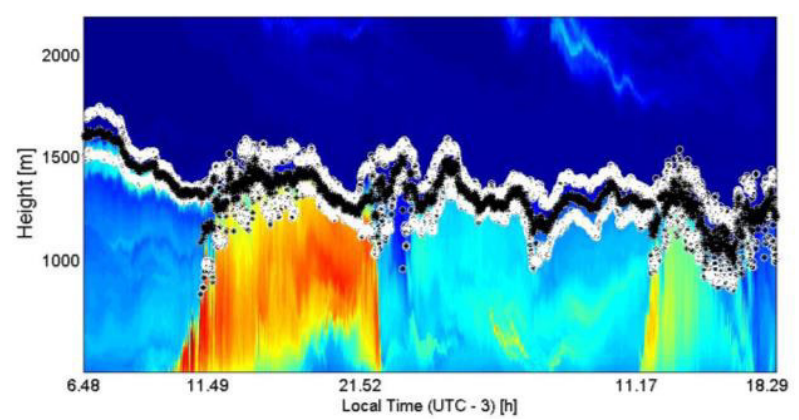

Figure 3. Boundary layers on May $9^{\text {th }}$ and $10^{\text {th }}$, obtained with covariance wavelet transform. The black line represents the $\mathrm{ABL}$ height and the white lines show the upper and lower limits of the transition zone. 
(a)

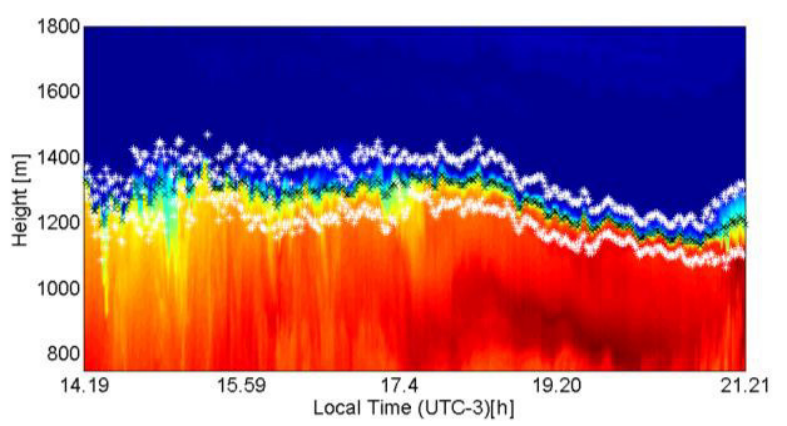

(b)

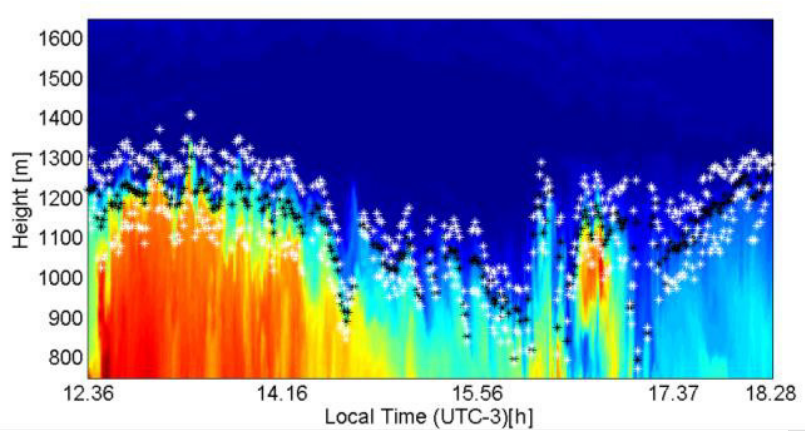

Figure 4. Transition Zone Thickness evolution, obtained with wavelet algorithm, during the monitoring of Chaitén volcano eruption on May 2008 in Buenos Aires. MLD on (a) May $9^{\text {th }}$ and (b) May $10^{\text {th }}$.

Table I presents statistical analysis for MLD and EZT on May $9^{\text {th }}$ and $10^{\text {th }}$. The $h_{2}$ and $h_{0}$ parameters are the upper and lower height of EZT.

Table I. Atmospheric boundary layer geometric parameters on May $9^{\text {th }}$ and $10^{\text {th }}, 2008$.

\begin{tabular}{|c|c|c|c|c|}
\hline Date & Parameter & $\begin{array}{c}\text { Mean } \\
{[\mathrm{m}]}\end{array}$ & $\begin{array}{c}\text { Standard } \\
\text { deviation } \\
{[\mathrm{m}]}\end{array}$ & $\begin{array}{l}\text { Maximum } \\
{[\mathrm{m}]}\end{array}$ \\
\hline \multirow{3}{*}{$\begin{array}{l}\text { May } \\
9^{\text {th. }}\end{array}$} & MLD & 1223 & 156 & 1391 \\
\hline & $\begin{array}{l}\text { Lower limit } \\
\text { of EZT }\left(\mathrm{h}_{0}\right)\end{array}$ & 1158 & 138 & 1350 \\
\hline & $\begin{array}{l}\text { Upper limit } \\
\text { of EZT }\left(\mathrm{h}_{2}\right)\end{array}$ & 1289 & 177 & 1470 \\
\hline \multirow{3}{*}{$\begin{array}{l}\text { May } \\
10^{\text {th. }}\end{array}$} & MLD & 1076 & 164 & 1357 \\
\hline & $\begin{array}{l}\text { Lower limit } \\
\text { of EZT }\left(\mathrm{h}_{0}\right)\end{array}$ & 1018 & 144 & 1290 \\
\hline & $\begin{array}{l}\text { Upper limit } \\
\text { of EZT }\left(h_{2}\right)\end{array}$ & 1133 & 188 & 1410 \\
\hline
\end{tabular}

\section{2.c.- Heat flux entrainment evolution}

The Entrainment Heat Flux ratio $\left(A_{r}\right)$ is calculated with the upper $\left(\mathrm{h}_{2}\right)$ and lower $\left(\mathrm{h}_{0}\right)$ limits of EZT. This ratio quantifies the amount of energy that is supplied to the ABL by entrainment process. The $A_{r}$ expression is shown in equation 1 .

$$
A_{r}=\frac{h_{2}-h_{0}}{2 h_{0}}
$$

The $A_{r}$ parameter takes values between 0.1 and 0.4 in atmospheres under free convectivity [17]. Figure 5-a shows the $A_{r}$ evolution on May $9^{\text {th }}$ between 2.19 and $10.21 \mathrm{pm}$ (local time). Figure 5-b shows the $\mathrm{A}_{\mathrm{r}}$ evolution on May $10^{\text {th }}$ between 12.36 and $6.5 \mathrm{pm}$ (local time). Both figures show that the dispersion exceeds the free convectivity limits with a value of $A_{r}$ smaller than 0.1 . On May $10^{\text {th }}$ most of measurements have a value of $\mathrm{A}_{\mathrm{r}}$ less than 0.1 .

(a)

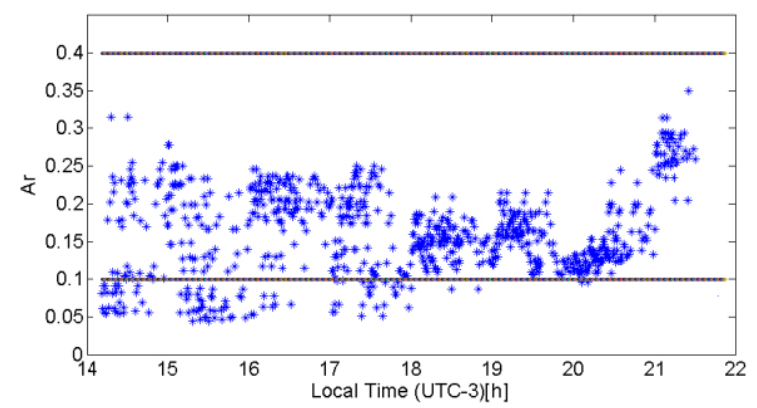

(b)

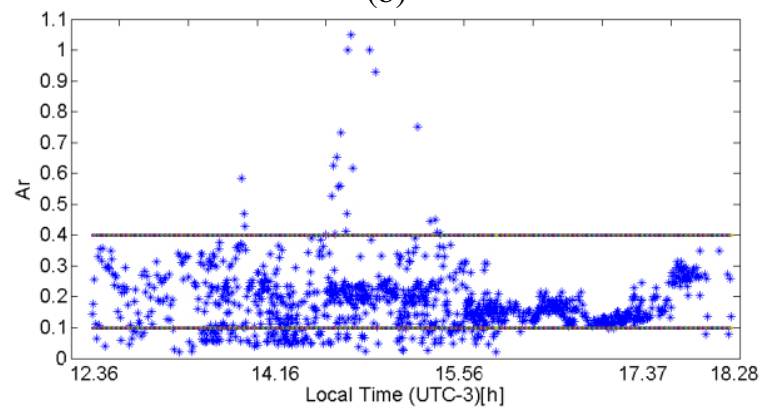

Figure 5. Entrainment Heat Flux $\left(\mathrm{A}_{\mathrm{r}}\right)$ evolution. (a) May $9^{\text {th }}$ and (b) May $10^{\text {th }}$.

The $\mathrm{A}_{\mathrm{r}}$ on May $9^{\text {th }}$ has a mean value of 0.1623 (with a standard deviation of 0.0576 ) and on May $10^{\text {th }}$ it has a mean value of 0.2407 (with a standard deviation of $0.1540)$.

\section{CONCLUSIONS}

An application of the wavelet technique was used to study the Buenos Aires ABL affected by the presence of volcanic ash. The method allows to extract from the lidar profiles the lower and upper height of the transition zone in order to calculate the entrainment heat flux. On May $9^{\text {th }}$, It is registered an maximum ABL height of $1391 \mathrm{~m}$ and a mean entrainment heat flux $\left(\mathrm{A}_{\mathrm{r}}\right)$ of 0.1623 (with one standard deviation of 0.0576). On May $10^{\text {th }}$, It is registered a maximum ABL height of $1357 \mathrm{~m}$ and a mean $\mathrm{A}_{\mathrm{r}}$ of 0.2407 (with one standard deviation of 0.1540 ). Finally, $A_{r}$ results are 
found below 0.1 on both days studied. This trend was more significant on May $10^{\text {th }}$, when volcanic ash plumes with greater aerosol optical thickness were recorded.

\section{ACKNOWLEDGMENTS}

Authors would like to thank JICA (Japan International Cooperation Agency) and JST through the Science and Technology Research Partnership for Sustainable Development (SATREPS) for supporting this work under the project: "Development of Atmospheric Environmental Risk Management System in South America".

\section{REFERENCES}

[1] Stull R. 1998: "An Introduction to Boundary Layer Meteorology", Kluwer Academic Publishers, Dordrecht, Boston, London.

[2] Loaec S., S. Lolli, L. Sauvage, M. Boquet, I. Xueref-Remy, 2009: An automatic Planetary Boundary Layer height retrieval method with compact EZ backscattering Lidar in the frame of ICOS campaign, American Geophysical Union, Meeting.

[3] Pallotta J., E. Pawelko, L. Otero, P. Ristori, R. D'Elia, F. Gonzalez, J. Dworniczak, O. Vilar. E. Quel, 2009: Monitoring Aerosol Optical Properties in the ABL, Using Lidar System and Sunphotometer in Buenos Aires, Argentina, Proceedings of the International Radiation Symposium. AIP Conference Proceedings, 1100, pp. 315-318.

[4] Sicard, M., C. Perez, F. Rocadenbosch, J. Baldasano, D. Garcia-Vizcaino, 2006: Mixedlayer depth determination in the Barcelona coastal area from regular lidar measurements: Methods, results and limitations, Boundary-Layer Meteorology 119, pp. 135-157.

[5] Seibert P., P. Kromp-Kolb, A. Kasper, M. Kalina, H. Puxbaum, D. Jost, M. Schwikowski, U. Baltensperger, 1998: Transport of polluted boundary layer air from the Fohn Valley to highalpine sites, Atmos. Environ., 32, pp. 3953-3965.

[6] Gamage N. and C. Hagelberg, 1993: Detection and analysis of microfronts and associated coherent events using localized transforms, J. Atmos. Sci., 50, pp. 750-756.

[7] Davis K, D. Lenschow, S. Oncley, C. Kiemle, G. Ehret, A. Giez, 1997: Role of entrainment in surface-atmosphere interactions over a boreal forest”, J. Geophys. Res., 102, pp. 29219-29230.
[8] Davis K., N. Gamage, C. Hagelberg, C. Kiemle, D. Lenschow, P. Sullivan, 2000: An objective method for deriving atmospheric structure from airborne lidar observations, J. Atmos. Oceanic. Technol., 17, pp. 1455-1468.

[9] Nemuc A., C. Talianu, L. Belegante, R. Ngo, C. Derognat, 2012: The boundary layer height and entrainment zone assessment from lidar, meteorological and forecast model data, $9^{\text {th }}$ International Symposium on Tropospheric Profiling, L'Aquila, Italy.

[10] Brooks I., 2003: Finding Boundary Layer Top: Application of a wavelet covariance transform to lidar backscatter profiles, J. Atmos. Ocean. Tech., 20, pp. 1092-1105.

[11] Flamant C., J. Pelon, P. Flamant, P. Durand, 1997, Lidar determination of the entrainment zone thickness at the top of the unstable marine atmospheric boundary layer, Journal BoundaryLayer Meteorology, 83, pp. 247-284.

[12] Ristori P., L. Otero, E. Pawelko, J. Pallotta, R. D'Elía, F. Chouza, F Gonzalez, J. Dworniczak, A. Pereyra, M. Fernández, S. Lema, N. Sugimoto, E. Quel, 2012: Development of an Argentinean lidar nework to monitor the volcanic plume and dust in Patagonia, Proceeding of the $26^{\text {th }}$ International Laser Radar Conference, Porto Heli, Grecia.

[13] Pawelko E., P. Ristori, I. Otero, R. D'Elia, A. Pereyra, O. Vilar, F. Chouza, J. Pallotta, F. González, M. Fernandez, M. Lema, N. Sugimoto , E. Quel, 2012: Multiwavelength Raman lidar construction to monitor volcanic ash and aerosols in Bariloche international airport, Argentina; Proceeding of the $26^{\text {th }}$ International Laser Radar Conference, Porto Heli, Grecia,

[14] Pawelko E., L. Otero, P. Ristori, E. Quel, 2008: Chaitén Volcanic Aerosol Transport Study During May 2008, Proceeding of the $25^{\text {th }}$ International Laser Radar Conference, St. Petersburg, Rusia, 1, pp. 215-218.

[15] Otero L., P. Ristori, E. Pawelko, J. Pallotta, E. Quel, 2011: Six-Year Evolution of Multiwavelength Lidar System at CEILAP, V Workshop on Lidar Measurements in Latin America, Opt. Pura Apl., 44, pp. 13-18.

[16] Baars H. , 2007: "Thesis: Continuous monitoring of the planetary-boundary-layer depth with lidar", University of Leipzig, Germany.

[17] Deardorff, J., G. Willis, B. Stckton, 1980: Laboratory Studies of the Entrainment Zone of a Convectively Mixed Layer, J. Fluid Mech, 100, pp. 41-46. 